DOI: 10.1515/auseur-2016-0013

\title{
Phenomena of Linguistic Interference in Old Hungarian Texts
}

\author{
Emese FAZAKAS \\ Babeş-Bolyai University, Cluj-Napoca \\ Department of Hungarian and General Linguistics \\ fazakasemese@gmail.com
}

\begin{abstract}
The analysis of interference is a popular topic in sociolinguistics, and the researchers addressing it investigate the phenomena of interference with a special regard to mother tongue texts of speakers living in a linguistic minority. In order to analyse the phenomenon, one needs to be clear about the identity of the author of the particular text, in addition to the linguistic environment, the circumstances in which the phenomenon appears, etc., and this is particularly difficult in the case of historical texts. The most frequent interference phenomenon in Old Hungarian texts is the occurrence of Latin elements in the utterances of Hungarian mother tongue speakers; nevertheless, we can find other linguistic interferences as within the regions inhabited by Hungarians the speakers came in contact with and learned the language(s) of several communities with other mother tongues. In this study, I analyse Romanian words and phrases that appear in the texts of Hungarian-language testimonies given by Romanians living in Transylvania; these linguistic elements cannot be classified as regional borrowings in the Hungarian lexicon, and if they can, they were used by the Hungarian speakers for a very short period of time. Thus, my paper analyses phenomena of interference that are connected to mother tongue elements appearing in a foreign language text.
\end{abstract}

Keywords: historical sociolinguistics, interference, Hungarian language, Romanian language

\section{Introduction}

Whether there is need for the renewal of the history of the Hungarian language has been a recurrent question of the past few decades. If there is need for that, why and in what direction? If there is not, are there any tasks, topics that need to be investigated? The majority of scholars answered the first question with a yes as research in the history of the Hungarian language seemed to be stagnating. Although the study of the language system involves the analysis of 
the lexicon, of meaning, of phraseology, this cannot be achieved with systematic knowledge alone; their changes are not triggered by the changes within certain sub-systems or their interactions: they are influenced by wider, socio-pragmatic or cognitive, psychological, human factors. That is why in the last third of the $20^{\text {th }}$ century more and more researchers turned to the various materials found in archives: the materials stored in private and state archives were published, including the texts of witch trials, and these generated an interest not only among historians, litterateurs, and ethnographers but among linguists as well. Approaching historical texts from the perspective of language use threw new light upon the language system, the processes of change within it, and, of course - probably most importantly -, research was completed with the human factor. Thus, language description from the historical point of view does not lack the speaker and the listener anymore, two major actors and doers of communication. The representatives of the new trend known as dimensional linguistics not only take temporality into account, but - as seen in the research on the geography of language - they have also started to analyse spatial changes and variations; this is complemented with the juxtaposition of the spoken and written language, the human dimension. We now have the possibility to take sociolinguistic and pragmatic aspects into account as well.

The analysis of interference is a popular topic in sociolinguistics, and the researchers addressing it investigate the phenomena of interference with a special regard to mother tongue texts of speakers living in a linguistic minority. In order to analyse the phenomenon, one needs to be clear about the identity of the author of the particular text, in addition to the linguistic environment, the circumstances in which the phenomenon appears, etc., and this is particularly difficult in the case of historical texts. Moreover, interference and code-switching are phenomena very close to each other, both possibly leading to loans in time although the terms borrowing and loanword are used differently according to the different authors' interpretations. ${ }^{1}$ I myself accept Lanstyák's (2006) definition, based on which the borrowings include the concepts of loanwords and foreign words previously used in linguistics. The analysis of borrowings is not the aim of this paper, I only refer to it tangentially. Regarding the difference between interference and code-switching, I accept Bartha's (1999) position, according to which code-switching is the manifestation of interference, and that is why I speak of interference and not code-switching in the texts analysed below. Interference is mostly found in the texts of bi- or plurilingual speakers, as a person speaking several languages can use the elements of two or more languages in one utterance. Thus, interference can function as an umbrella term for all linguistic phenomena that result from the fact that the bilingual speaker uses more than one language in everyday interaction (Bartha 1999: 118). 
The most frequent interference phenomenon in Old Hungarian texts is the occurrence of Latin elements in the utterances of Hungarian mother tongue speakers; we can also find other linguistic interferences as within the regions inhabited by Hungarians the speakers came in contact with and learned the language(s) of several communities with other mother tongues, and as a result they could use foreign linguistic elements in their mother tongue texts without loaning these elements afterwards. However, during the editing process of the Erdélyi magyar szótörténeti tár (Transylvanian Hungarian Historical Thesaurus - henceforth SzT.), I noticed a phenomenon that is different from 'more usual' phenomena that are analysed. It is a general trend in sociolinguistic research for foreign elements in mother tongue texts to be the subject of investigation. What sparked my interest was not the high number of mother tongue words used in mother tongue texts: in the Hungarian-language testimonies made by Romanians living in Transylvania, there is a substantial number of Romanian words, phrases which cannot be classified as regional borrowings in the Hungarian lexicon, and, if they can, they were used by the Hungarian speakers for a very short period of time. Thus, my paper analyses phenomena of interference that are connected to mother tongue elements appearing in a foreign language text. At the same time - when related to my topic -, I discuss Romanian elements found in the texts of Hungarian mother tongue speakers as well.

\section{Emerging Issues and the Corpus}

The analysis is performed on texts produced in 16-19 th $^{\text {tcentury }}$ Transylvania or in Romanian principalities, texts that constitute the material of the SzT. The texts are either testimonies or letters the authors of which are positively Romanian mother tongue speakers. The most important criterion is thus the fact that we know the identity of the author for certain. Moreover, the location where these texts were taken down is also not indifferent. On this basis, we can most likely assume the ethnicity and mother tongue of the scribe even if we have no other way of knowing it. In the majority of the cases, we have information about the ones testifying, as the scribes had to make accurate notes regarding that. The scriveners of the reports and accounts of censuses, urbaria, and granges are known to mostly having Hungarian as a native language except for those regions where Romanian or Saxon mother tongue speakers were hired to perform such tasks. The regions where the scriveners are most likely Romanian speakers are: Alsó-Fehér County, the southern part of Hunyad County, the Hátszeg and Fogaras Regions, as well as the eastern part of Banat (cf. Lukács s.a., Lukács 2004, Nagy 2012). Because of the absence of accurate data, I only included texts in my analysis in the case of which the confessor or the scrivener is a Romanian native speaker without a 
doubt. In this period, the correspondence of Moldavian and Wallachian voivodes, statesmen was usually aided by Transylvanian Hungarian scribes (Jakó 2012); thus, most of such texts cannot be included in the study. Although this implies speakers of at least two languages, Hungarian and Romanian, their mother tongue was most probably Hungarian. Only the letters written by Romanian mother tongue scribes can be included in this analysis.

The temporal and geographical distribution of these data is interesting. Most of them date back to the $18^{\text {th }}$ century, although we find texts with interference phenomena from the $16-17^{\text {th }}$ and the $19^{\text {th }}$ century as well. ${ }^{2}$ Their geographical distribution is the following: 59 of the 275 data was taken down in Hunyad County, 40 in Szolnok-Doboka County, 31 in Kolozs County, 31 around Fogaras, 26 in Alsó-Fehér County, 23 in Torda-Aranyos County, and 20 in Maros-Torda County. ${ }^{3}$

As mentioned above, I do not analyse words, phrases that were or are part of the Hungarian language as regional borrowings. There are some exceptions, however: cases in which - although adapted to Hungarian phonotactic rules in the speech of Hungarians, or having been used by Hungarian speakers - the phonetic variety in the text is identical to the Romanian dialectal or standard variant, and its author is without a doubt a Romanian native speaker. Such examples are kláka, szkutár, or manasztira, which as borrowings are used in the variant forms kaláka ('work party, work bee'), eszkotár iszkotár oszkotár ('shepherd'), monasztéria $\sim$ monosztéria monosztíria ('Orthodox monastery'), but the Romanian speakers use their native language variety. E.g.: 1633: Minketys hivot Clakaban Pentek es egieb Innep napokon [A.venice F; Szád. Lupul Myhaczy (80) vall.]; 1752: midŏn bujdosoban volt Avrám, ŏszve beszéltem volt az Feleségével hogj klákát csinállyunk [Abrudfva/Abrudbánya AF; Ks Barna Marjucza Bráskovics felesége (33) vall.]; 1806: mennyit nem dolgoztanak még Klákába azért Sípos Vaszilikának [O.bölkény MT; Born. G. XIII. 5 Nobilis Popa Trutza Alexandru (58) parochus gr. ritus unitorum vall.]; 1729: mondá még Kálnoki Farkas Ur Prov. Joh. Szkutárja valék [Apáca Br; BrÁLt IV. 15 Prov. Joh. oláh judex poss. Apátza vall.]; ${ }^{4}$ 1742: kezdé Dán Furdsat szidni káramolni, mondván baszam lelkedet, keresztedet, Evangeliamodott és Manasztiradat [Bulzest H; Ks 111 vegyes ir.]. ${ }^{5}$

I found one interesting instance when the Romanian confessor uses the Hungarian equivalent of a word, while the utrum contains the Romanian word:

2 The temporal distribution can be explained by historical facts that exceed the scope of this paper (cf. Nagy 2012, Lukács 2004, Lukács s.a., Prodan 1970).

3 The remaining data are divided between 10 counties, and their number is very small compared to the above.

4 Nevertheless, we have examples for the opposite, meaning that the Romanian speaker uses the form with the epenthesized vowel in the consonant cluster. 1757: és Iffiu koromba is Eszkotára vóltam Lázár Ferenc úrnak [Gyszm; DE 3 Demetrius Vad (74) jb vall.].

5 Although we do not know the identity of the person confessing here, based mainly on the phonetic variety as well as on the settlement, it is not impossible to state that the author of the text is Romanian. 
1708: (Az) Udvarházhelyen igazé hogy Pro nume egy nyomorult Hruba vagyon [Kissármás K; Rlt O. 4 vk. A hét román jobbágy vall-ban házotskák-ról emlékeznek meg]. As the interrogation contains the dialect variant of hruba 'earth hut' and not huruba, which is generally used in Hungarian texts (Cf. hurubácska, hurubás, hurubaház, lakóhuruba, zsellérhuruba, etc.), it is possible that the interrogator was also a Romanian native speaker.

\section{Interference Phenomena}

The majority of interference phenomena are one-word lexical code-switching; most of these Romanian words are used in Hungarian texts because they can be considered realia or culture-specific words. Thus, we have to deal with objects and concepts characteristic of the Romanian culture and everyday life, and as such they have no exact Hungarian equivalent; they also might be used in their foreign forms to separate them from the ones that are part of the Hungarian culture and everyday life. Most of such realia can be found among concepts related to customs, religion, certain professions, units of measurement, clothing items, foods, drinks, as well as functions. Of course, not only such phenomena, concepts, and actions can be included here: we find mother tongue words in foreign language texts from all walks of life.

\subsection{Lexical, Single-Word Interference}

3.1.1. In the field of occupations, we find the following words: bárdás 'carpenter, carver' (1793, 1805), ${ }^{6}$ dászkel dászkál 'cantor (teacher)' (1747, 1792), szkutár (eszkotár iszkotár oszkotár) 'stock-keeping shepherd', 'stock-keeping herdsman' and 'grange-keeper' (between 1632 and 1757); gornyik 'forester', 'border watch' (between 1726 and 1825); hajtás 'ranger' (between 1805 and 1812); jungár 'boy helping miners' (1806); mósa 'midwife' (1724, 1831); munator 'herd attendant' (1766)', pakurár 'shepherd' (1687, 1744, 1757); piszár 'scrivener' (1656); pitár 'baker' (1656); plájás 'border guard’ (1650); podar 'ferryman’ (1746, 1760, 1808); porkár 'swine-herd' (1715); vákár 'cowherd'; vocsinik 'apprentice’ (1778); zsitár 'border watch’ $(1756,1773)$.

Most of these refer to occupations mostly performed by Romanian mother tongue people, such as gornyik, szkutár, munator, pakurár, plájás, porkár, and vákár. I have previously presented the phonetic varieties szkutár can take in the speech of Hungarian and Romanian mother tongue speakers, respectively. We also consider pakulár to be a regional borrowing, but we have three instances where the transcribed variant refers to an interference phenomenon (pakurár cf.

6 The dates in brackets refer to the year of the taking down of the text. 
Rom. păcurar): 1687: monda Komsa Mark a’ pakurarnak [Huréz F; Szád. Kriszta Czigany (40) jb vall.]; 1744: en ő nekiek Pakurárjak voltam [M.pete K; SLt AY. 7 Molduvánj Jeftimie (55) zs vall.]; 1757: vóltam Pakurárja Lázár Ferencz Úrnak [Szárhegy CS; DE 3 Simon Czepelŭs (60) jb vall.].

The words dászkel dászkál, mósa, piszár, podár, etc. appear as such in the texts as they refer to Romanian individuals. For example, the term dászkél was only applied to Romanian cantor teachers, and as such they refer to Romanians in texts of testimonies, too: 1792: (Popovits Péter) el mént a Bánatusba Deszkélnek ('Popovits Péter left for the Banat to become a deszkél') [F.lapugy H; Ks XLVIII/7g özv. Popovits Györgyné gr. kel. papné vall.].

The following text contains both the terms bába and mósa ('midwife'), the Romanian word denoting the ethnicity of the person, while the Hungarian word referring to the occupation: 1831: Mosája a Feleségemnek tanult Bába Asszony Isztrátyi Demeterné volt [Dés; DLt 332.11].

3.1.2. Among the functions we find the following words: dzsugya $\sim d z s u g y e$ 'village judge', 'court judge' (between 1681 and 1794); jegumen 'superior general' (1757), kaluger kalugyer 'Orthodox monk' (1714, 1757); krisznyik 'sacristan' (1784), parintye perintye 'name of Romanian priest' (1765), szindia 'village judge' (1633), vladika 'Greek Orthodox bishop' (1714). All of these names are used in the parlance of the Orthodox or Greek Orthodox Church, and they also refer to the fact that the particular functions are held by Romanian individuals. This last category contains the term dzsugya dzsugye 'village judge' as well, data for which were found in Hunyad County and Beszterce-Naszód County.

3.1.3. There is one term in the category of units of measurement: patrarica 'quarter of a bushel'. However, the text of the testimony includes not only this one Romanian word, but also tébujéc meaning 'small sack': 1836: bé jŏvetelekkel egy Tébujétzban egy vékánnyit hoztak bé Gabonával ... az édgyik Cseléd ... azt a Tébujétzot a Szekérhez ki vitte, és Tŏrŏkbuzát hozott osztán bé, pálinkáért mint egy Patraritzát fizettek [Kendilóna SzD; RLt Zsimán Silipp (52) vall.]. Note that the Romanian professor uses a back-vowel suffix with the word tébujéc. This also demonstrates that it is an interference phenomenon, as a Hungarian native speaker would have used a front-vowel suffix.

3.1.4. The following words can be included in the group of clothing and accessories: babó 'woolen coat' (1797, 1798), csercseje 'earring' (1800), ${ }^{7}$ szálba 'necklace’ (1742), szárika ‘(baize)coat' (1739), zgárda 'necklace’ (1731).

3.1.5. Among the foods and drinks, we find mainly terms related to sheep breeding: bálmos 'a dish made from corn flour with sheep cheese, sour cream or butter' (1652), kaskavál 'sheep or goat cheese' (1827), kuretor 'type of cheese'

$7 \quad$ It is to be noted that this word appears identically in the SzékK. (és fel wéwe az o yogyanak $\mathrm{o}^{\mathrm{e}}{ }^{1}{ }^{\mathrm{e}} \mathrm{z}$ etyth liliomyt, fo leybevalo éékes čerčel'eyth). Here, however, the drafter of the text is a Hungarian mother tongue speaker, and thus it is not related to the topic of the paper. 
(1805). This group also includes krupa 'barley porridge' $(1683,1685)$, munkatura 'food aid' (1822), as well as szuszla 'first-brew pálinka' (1832).

3.1.6. The following terms, phrases can be included in the group related to customs and religious life: ármingyin 'maypole' (1749), picere 'chanting' (1819), pomána 'funeral reception' $(1730,1739,1749)$, preszkura 'sacrificial bread' (1722), prohod 'funeral, burial' (1768), prohodálás 'burial' (1722), prohodálatlan 'without funeral rites' (1722), szerekuszta '40-day-long prayer for a deceased/ ill person' (1765), ruga 'prayer' (1765), jertecsuna 'pardon, saying goodbye to a dying person' (1810), léturgyia 'liturgy' (1811), szluzsba ‘Orthodox mess' (1757), szerindár 'mess of atonement' $(1768,1804)$.

It is also frequent that the Romanian word is embedded into the Hungarian text with Hungarian suffixes. This is especially interesting when they use képző-type (derivational) suffixes and not jel-type or rag-type suffixes (inflectional suffixes) of utmost importance to Hungarian syntax, as the latter are crucial syntactic elements and as such cannot be missing from a Hungarian text. This can be found in two testimonies from the same settlement in Szolnok-Doboka: 1722: Egj leánykám meghalván; a p(ro)hodálására hitta(m) az Berlai (!) Papot [Kecsed SzD; TL. Podár Juvon (42) prov. vall.] I egy Gyermekemet p(ro)hodalatlan Temettem el oda ne(m) hihattam ${ }^{a}$ [Kecsed SzD; TL. Hrubán Gavrilla (38) prov. vall. - ${ }^{a} A$ papot]. Meanwhile, later texts from Hunyad County contain forms similar to the Romanian standard variety (Cf. provod, dial. prohod): 1768: halálakor hagyta hogy az Evangeliumat olvassam, méllyért negyforintot defálcalt, és aztis hagyván hogy Provodotis szolgállyak ritusunk szerént [Vályebrád H; Ks 81. 57/17 Popa Gyorgy gör. kel. pap vall.].

The rites described in the appendices are described by phrases that confirm the fact that the individuals confessing are Romanian native speakers, as the verb tesz 'to do' / 'to make' is a loan translation of Romanian phrases. Pl. rugát tesz 'to pray' (1765: belém áll az nyavallya, elég rugát tésznek a Papok ... de tsak nyavallyában vagyok [Marosbogát TA; Mk V/97 Rusz Gavrilláné Popa Anucza (72) zs vall.]); szluzsbát csinál/tesz 'to celebrate a mass', as well as 'to bless' (1722: Slusbat ... Pap Péter ur(am) ne(m) tótt I(ste)nni szolgálatott reá, hanem ugj hoztuk ki az Templombúl Penyiszessen [Kecsed SzD; TL. Makra Szavúl (50) prov. vall.]; 1757: az én Apám Popa lévén magátis a megnevezett Szakare Szimion eltemetvén minden költség nélkúl, a mint a mi rendûnken szoktak Szlusbákat csinált az Apám utánna [F.borgó BN; BK. Popa alias Flemind Andréás (55) jb vall.]); szerekusztát csinál 'prays for 40 days for an ill/deceased person' (1765: azt fogta volt réám, hogy Nyágujnak Szerekusztát tsinyáltam [Marosbogát TA; Mk V/V. 97 Popa Lup (30) pastor eccl. vall.]).

The verb szolgáltat 'to serve, to provide, to supply' also appears; however, it is part of the testimony of the same priest, quoted above as example for the word 
provod (Cf. with another testimony: 1768: 12, forintért egy szerindárt szolgáltam [Vályebrád H; Ks 81. 57. 17 Popa György gör. kel. pap vall.].)

3.1.7. In the case of words referring to origin, we have only one example for interference: muntyán 'from the mountains' (1700): 1700: Az utrumban Specificalt Személlyeknek az Attyokat hitták Opris Peter(ne)k; és nem Csonokosi örökös jobbágj vólt, hanem Havasoly földi Muntyán volt és onnan származat ki [H; Szer. Dumitru Sandon (50) jb vall.].

3.1.8. Words denoting different human and kinship relations are very frequent in the texts of Romanian testifiers. This group includes the following: dusmán 'enemy' (1656), fertát 'fellow, companion' $(1728,1752)$ frátye 'companion, buddy' (1756, 1759), mujere 'woman', 'wife' (1762), sinuj 'buddy' (1806), szamunca szemunca 'offspring, relatives' (1715, 1718, 1743, 1753), unty 'uncle' (1740, 1765), matusa 'aunt' (1740, 1764), nyepót 'nephew' (1756), nanás 'godfather', 'best man' (1777, 1800, 1804), kumnát (dial. komnát) 'brother-in-law' (1725), kuszkru 'in-law' (1769).

There is only one example in texts of letters (1656: Irja Stefán vajda ő nagysága az dusmánya dolgát istenre hagyja [RákDiplÖ 443 Balogh Máté erdélyi kapikiha Konstantinápolyból a fej-hez]).

All other instances are found in texts of testimonies, and they always refer to a Romanian person. Pl. 1715: Tudok más darab kaszállót is ... Popa Pétru ... vetette zálogban közel száz forintba Sinár Pétrunak, kinek a Felesége ugjancsak abbol a szemuncabol valo [Ponor TA; WH. Czir Nikula (66) vall.]; 1725: Barna Birtolomély ... most Besztercze székben egy Sude Paskuly nevú Comnattyoknál commorál [Körtvélyes SzD; BK. Buta Birtolomej (78) vall.]; 1740: Engemet kúldőtt Demeterpatakára a Koszta Sztephán Felesége egy Jovanitza nevú matusájához [Herepe AF; BK. Herepei lev. Honesta Feomina Flora aluj Ruszán Kopatzin (35) vall.]; 1806: Pap Demeter el ment a Varázsló Asszonyhoz Babtzára, és magával el vitte az Exponenst is mind Sinujját [A.várca Sz; IB 130/1 Papp Urszully (24) ns vall.].

3.1.9. Almost all terms from wildlife, names of animals and plants are included in the Transylvanian Hungarian language variety. The majority of such terms are related to sheep and goat husbandry; they are regional borrowings from the Romanian population because the Hungarian community did not use different names for 1-2-year-old, young animals or to designate the utility or species of such animals: Hungarian speakers usually use adjectives for this purpose. ${ }^{8}$ Thereby, it is actually possible to consider this borrowing: in the texts of Romanian speakers, we seldom find instances where there are phonetic or any other differences from the forms used in Hungarian. Perhaps the only word that can be included in our analysis is turma meaning 'flock', which is mostly used

8 Cf. the words kirlán 'one-year-old lamb'; mióra 'young lamb (until the age of 3)', as well as 'oneyear-old goat'; plekatura 'dairy sheep'; szterp 'barren sheep', etc. 
in testimonies of Romanian native speakers. Pl. 1763: Tudom azt hogy Mányika Iuonnak volt Circiter tiz vagy tóbbetske Juha aprostol edgyútt, a’ melyeket az Uraság Juhaítol kűlőn jártotat, ezek mind a’ Marsinának Turmájábol valok voltak [Záh TA; Mk VII/1. 16 Sarmasán Gabrilla jb vall.]; 1829: ifiab koromban pakulár voltam kőzel jártunk azonn a vidéken egymáshoz a’ Ditraiak Turmájával de ŏk soha ezenn Hellyre ... a Turmajokkal által nem jŏttenek [Toplica MT; Born. XVc. 6 Voda Vaszilia (77) vall.].

Similarly, we find few instances of interference in the variants of plant names. This group includes faszuly 'beans' (cf. the Transylvanian varieties fuszulyka, paszuly 'beans'; as the appendix is fairly late, the person testifying is a Romanian native speaker, as by this time the variant fuszulyka, paszuly are generally used in the Hungarian language across Transylvania: e.g. így engedte el a’ Kender munkát ... Kendermagot, faszulyt s egyebeket is [Zsibó Sz; WLt Florica Fátzán (25) vall.].

3.1.10. In the case of names of illnesses, only the word csoma $\sim$ csuma 'plague, pestilence' can be included in our analysis, although it was widespread among Hungarian speakers in the $18^{\text {th }}$ and $19^{\text {th }}$ centuries. Nevertheless, Hungarian testifiers mostly used the variant with $o$ (we have no instances - not even from earlier centuries - that have the $u$ phoneme - cf. Rom. ciumă). Therefore, and also because the Romanian testifier quotes a Romanian native speaker, I can confirm that the 1744 data represent in fact an interference phenomenon. Nehai Gruz Todor Meg hagyatott ŏzvegye Óltyán Ráda Maros szekben Uraljban lakó (58) ... Fassa est sic Tuda bizanyasan mondani, Mível Nehai Grúz Todornak én voltam Másadik Felesege ... Kormas Maríát az előttem Valo Felesegetís ígen jól ísmertem ítten Maras szekben Uraljban holt vala meg Csumában [SLt A et Y Nro. 7].

3.1.11. Among the names of utensils, tools, and weapons we find the following words: csafling 'iron wedge with ring and chain' (1803), rugyica 'small rod, pole’ (1796), cepusa ‘stanchion’ (1796), donyica 'wooden churn’ (1752), fustély 'pole' (1585), galáta galyáta 'wooden pail (1808), hirgó 'cooking pot' (1762), ${ }^{9}$ kompona 'hooked scale' (1769), macsuka 'club' (1767), rezsnyice rozsnyica 'quern, grinder' (1796). Let us see an example where two of the above words can be found: 1796: Tkts Csernátoni Ur(am) Czigánnyai ... belénk akadtanak Czepusával, Vas Villával, és rúgyitzával űtettenek, vertenek [Mocs K; Eszt-Mk Nyikita Nyikuláj (25) béres vall.].

3.1.12. Among the names of buildings, besides the abovementioned hurba huruba, monasztéria, only kilia 'little hut, hovel' can be considered a phenomenon of interference. (1726: lattamiis (!) Hogj opra popa kallugyer Fellessege Sztanka Aszszony az erdőben Levő killiajaban Főzőtt egetbort [A.árpás F; TL BB. X/30 Popa Szimion falu papja (28) vall.]). In other cases, besides the ethnicity of the author of the text, we have no other information that

9 Hirgó in fact is a Hungarian-origin word in Romanian, reborrowed and frequently used by 16-17 ${ }^{\text {th }}$-century Hungarian speakers in Transylvania (cf. Tamás 1966). 
would point to the existence of interference, as such words were used in the contemporary Hungarian language in Transylvania.

3.1.13. We can find, however, an abundance of examples regarding names of parts of settlements and geographical names: brányista 'mower' (1757), delnice 'small strip of land' (1717), fundatura 'hollow' (1743/1744), ferdela 'ancient (boyar) land' (1680/19. sz. eleje), jáz 'ditch' (1757/1758), kuratura 'cutting' (1784), lunka '(water) meadow' $(1715,1815)$, mátka 'riverbed' $(1746,1843)$, mosia 'estate' (between 1665 and 1780), paró 'riffle' (1777), pláj 'mountain path, border trail' (1803), pojána 'glade' (1714, 1728, 1803), pojenica 'small glade' (1782), rozor 'furrow' (1763), szeketura ‘barren hill or mountainside' (1804), zmnyida 'thicket, greenwood' (1803).

The word brázda 'furrow' can also be included here, in the case of which - based on the variant and date - it is certain that at least one instance can be considered an interference phenomenon (1697: az Var megje Tiszteit ki vitŭk akor brázdálták fel az határt, és azan brázdáig mint nagj Barcsiak (!) birtak ... eő Nga gondviselője a brázdán belől Szántatott [Nagybarcsa H; BK sub nro 281 Serban Ignát (80) jb vall.]). This is because by that period the word of Slavic origin was already used in the forms barázda or borozda in Hungarian.

3.1.14. The rest of the words and phrases can be included in a variety of conceptual groups: bácsokura 'mockery, insult' (1763), norok 'luck' (1757), cinemintyés 'vengeful' (1756), vájdemine 'woe is me!' (1723), porekla 'surname', 'nickname' (1730, 1740), dát '(sheep) grazing service' (1700, 1701), globa 'fine' (1760), sugubgyina 'fine' (1761), kolák 'the sum paid by the injured part for finding a perpetrator' (1651), ruptura 'agreement with the landowner regarding services' (1761), kuptor 'baking oven' (1720), papusa 'bundle' (1849), butuk 'tree trunk, stump' (1754), sztupatura 'dam, padding' (1763), as well as the aforementioned kláka 'work bee'. Pl. 1740: A kérdésb(en) forgo Nyikitát hallottam magától hogy a’ Poreclája Oltyán volt [Pujon SzD; WassLt Moldován Vaszil (28) zs vall.]; 1756: Tudom hogj Molduán Vonya tzinemintyés ember [Galac BN; WLt Rob Thodor (40) jb vall.]; 1757: Koszta tsak kiáltatta a' tolvajt hogy mennyünk az eö norokjára 500 forint birság alatt [Erdőalja KK; Ks 66. 45. 17g Hánk Péter (34) jb vall.]; 1763: az szomszédságb(an) lévő rétb(e) annyira nem szántottak mint ebbe(n) a Mikes részre valoba(n) az tsak batsokura [Széplak KK; Ks 82 hat r. tanú vall.]; 1849: 4 papusa Dohányt enis el vettem volt [Héjasfva NK; CsZ. Teskula Demeter (33) vall.].

In Old Hungarian spoken in Transylvania, the Romanian-origin words kalács, kalák 'sum paid for investigation' appears as kolák in a testimony given by a Romanian native speaker (cf. Rom. colac): 1651: az Budatelkj karos embernek kolak penzet 12 forintot veottek fel Kata Istua(n) es az tarsa Farkas az kolak szerint nem praestaltak igireteket [Lompért K; WLt Bota Tiuadar (35) jb vall.].

3.1.15. Among the analysed words, there is a significant number of verbs with Hungarian verbal suffixes, as otherwise they could not be interpreted 
as verbs in any Hungarian text: dezlegál 'to absolve' (1722), fututál 'to curse' (1687, 1748), kintálódik 'to ululate, to whine (1761), kommunikál 'to administer Holy Communion' (1570), kommunikáltat 'to administer Holy Communion' (1780), szokotál 'to consider, to think about sg' (1831), szokotálhat 'to count on sg' (1775/1781). Pl. 1570: en azt mondom az Zent irassal, mert eok igazan nem comunikalnak mikeppen Christus parancsol [Lámkerék Szb; Hurm. XVI/1. 646 Tordasi Pál román püspök a beszt-i királybíróhoz]; 1687: Raduly ... egy nehanszor fututala az Annyat, Opra es Many Hertsegja Csititak Komsa Markat hogy ne üsse(n) hozza es ne szidgya az Annyokat [Hurez F; Szád. Salamon Stira Boer (71) vall.]; 1722: Egj leánykám meghalván; ă p(ro)hodálására hitta(m) az Berlai (!) Papot; mikor az Templomb(a) bé mentúnk, meg irt Berlai Pap hitta Pap Péter uramat, hogy dezlegállya, de el ne(m) jőtt, annak utanna adtam Négj máriást; de mind eddigis én hiremmel ne(m) dezlegálta [Kecsed SzD; TL. Podár Juvon jb vall.]; 1831: egyébre felelni nem tudok minthogy nem igen szokotáltam [A.csernáton Hsz; HSzjP Provid. Thodor vagy Vántsa György (24) vall.].

The most interesting part is not the presence of Romanian verbs with Hungarian verbal suffixes but the fact that there are instances of variants without preverbs: egybefututál 'to scold, to rebuke' (1774), összefutul 'to scold, to rebuke' (1714), megkokosál 'to rape' (1723), elzohol 'to banish, to chase away' (1801). Pl. 1714: öszve futulának benünket Ezt mondvan jertek hajcsuk ki meg az kukuruczajakbol is őket [Kisdenk H; BK sub nro 261 Fatuly Kasaska (70) jb vall.]; 1801: amig viszsza érkeztem az irt Tarsom el szalasztatta, a meg arestált őkrőket $s$ a mellette levő személy el-zoholta a városi Erdőre [Koronka MT; Told. 10 Binda Vaszily (30) határpásztor vall.].

\subsection{Quotations}

Lexical interference also includes instances where the person testifying quotes the speech of a Romanian native speaker. These are seldom longer than one-word quotations. Pl. 1756: Petika demeter ... monda nékem mi dolog ez Fratye Biro, hogy most közelebb harom nap jarok a Kantzámon Rusra s mostis hurtzolyátok mellyre mondék fratye Demeter Semmi baja nintsen a kantzádnak [Bencenc H; BK Misc. 1143 Tót Togyer (35) judex pagi vall.]; 1761: kiáltotta Lup Togyika hogy ûssétek ... őljétek meg mert vagyon még egy tehenúnk meg fizethetyúk a' Sugubgyináját [Illyésfva Sz; BfR 45/9 Horvát Juon (30) zs vall.]; 1762: az éjjel bé jöve Apám ... Anyám már alutt és fel költvén aszt monda kely fel mujere [Gyeke K; Ks 4. VII. 12 Petka cons. inquilini Molduván Nyekita (33) vall.].

Sentence- or syntagm-long quotations can only be found in texts produced by Hungarian speakers; however, this is not the topic of the present study. One exception is vajdemine 'woe is me!' (1723: én a lovakat helyheztetém el azonb(an) hallok nagy puffogást vajdeminét [M.hodák MT; VGy. Prekup Ojnicza (40) jb 
vall.]), as this is a phrase containing three words; the testifying person, however, uses it as one word.

\subsection{Explanations}

In some of the texts, the Romanian words are explained by their Hungarian equivalents. In other cases, the speakers utter the Hungarian and Romanian words one after the other. Pl. 1803: egy tisztás hellyból, Pojánábol valami hat vagy hét Remetei Fegyveres Székelly Katona a’ Juhait ... Remete felé már hajtottákis [Várhegy Cs; Born. XVc. 1 Iuon Dobrán (40) col. vall.]; 1808: a Groff Juonnak ... egy Galyatáját, Sajtárját ... el vetette volt [Szászerked K; LLt Szent Mihelyán Toma (33) vall.].

Frequently, they add the words azaz 'that is', vagyis 'namely', oláh nyelven 'in the Vlach language' or oláhul 'in Vlach'. 1633: az Boerok szabados Emberek, es az szegenyseg is Szindiakys az az az Birak [F.venicze F; Szád. Sztan Paszerey (45) vall.]; 1745: esmertem Rusz Gyurkát is ki ... Csimponér vagy is Dudás lévén [Halmány H; Ks 101]; 1755: az holottis most ... Kólóst vagyis Malájt vetettek volt, és ennek előtte kaszálni nem lehetett ... eddig az hellyig ameddig az Malaj vagyis Köllős vagyon megengedem hogy kaszálj [Oprakercisora F; TKhf 31/11 Iuon Boerás (60) jb vall.]; 1761: az oljan helly hogy mindenkor a’ Dominus Terrestrisekkel rupturájok vagyis oljas Conventiojok lévén a' hogy megalkhattak, pénz s egyéb táxát fizettek [Sztanisa H; JHb LXVIII/2. 14 r. tanúk vall.]; 1768: az Emberek ... el vezettek engemet az régi mosijajahoz, vagyis lako hazahoz [Katona KK; Born. XL. 80 Kotis Todor (40) zs vall.]; 1777: éppen azon árokig vagy is paroig kelletik ezen földnek rugni [Gambuc AF; KP. Csora Juvon (85) jb vall.]; 1803: Ezen Ösvenyen vagj Plajon belöl [Gyszm; Born. XVc. 1/20 Antonius Moldván alias Csorsza (48) civis vall.] I itt az Orosztűknél az also Vészt, vagy veszet vagy romlást, oláhul Zmnyidát, Topplitzához ... értem biratni [Gyszm; Born. XVc. 1/16 Jacobus Petyekár alias Küs (83) vall.]; 1811: Midön az Egés volt Harang fére verés nem volt, Sem Tolvaj kiáltás, Mivel a’ Papunk az Templomba lévén Miset szolgaltatott, azaz Léturgyiát [Cold K; JHb 5. 3/3 Stéfán Gyérán (50) col. vall.] I a’ Pap éppen akkor szolgáltatott Misét, vagy is Olá Nyelven Léturgyiát [Cold K; JHb 5. 3/3 Ungur Toma (32) col. vall.].

There are, however, explanations originating not from the person testifying but the person making the notes. ${ }^{10}$ These are sometimes longer and contain the description of the meaning of the Romanian word. Pl. 1803: a' Gyitrai Communitas el vett ... egy Testvéremtől ... egj lántzot, két csafflingját (: a’ melly valami hasitto szeg forma vas, a' melljet a' Tókékbe szoktunk ütni, ’s az ahoz foglalt karikákba

10 In the explanations discussed above, it is possible for the scribe to have inserted the Hungarian equivalents in the Hungarian text; however, this can be surely stated only in the case of insertions in brackets made at the time of recording the text. 
akasztyuk a lántzot :) [Toplica MT; Born. XVc. 1/122 Bukur Juonást senior (86) col. vall.]. The explanation, however, can consist of only one word, which is included in brackets in the text by the scribe. Pl. 1715: a Vŏlgjben volt valami darab Lunka (: kaszálo :) a mellj akkoris, mostis Magosnak hivattatott [Ponor TA; WH. Pracze Flora (64) jb vall.].

\section{Conclusions and Further Tasks}

Most lexical interferences in foreign, Hungarian language texts produced by Romanian native speakers can be dated to the $18^{\text {th }}$ century. A significant part can be classified as realia or culture-specific words (denoting customs, phenomena related to religious life, buildings, functions, specific foods, etc.), and there is also a large number of words in the case of which the texts of testimonies contain the Romanian equivalent as a strategy to point out the mother tongue and the ethnicity of individuals.

A further analysis on Romanian phrases and words included in the speech of Hungarian native speakers, their form varieties, their frequency, as well as their derived forms and compositions would be important to conduct. Their temporal and geographical distribution is also significant. Upon completing the two studies, we could not only map the word use of various regions and individuals belonging to different social groups but the analyses could also be compared in order to get a more nuanced picture of the language use habits of speakers from this period. Of course, we should always keep in mind that in the case of historical texts - due to the lack of data - some questions cannot be unequivocally answered.

\section{References}

BARTHA Csilla. 1999. A kétnyelvúség alapkérdései. Budapest: Nemzeti Tankönyvkiadó.

JAKÓ Klára. 2012. A 16. és 17. századi moldvai és havasalföldi vajdák és főtisztségviselők magyar nyelvú leveleinek nyelvi sajátosságairól. In: DÁNÉ Veronika-OBORNI Teréz-SIPOS Gábor (eds), „... éltünk mi sokáig 'két hazában'..." Tanulmányok a 90 éves Kiss András tiszteletére. Debrecen: Debreceni Egyetemi Kiadó, 233-242.

KISS Jenő. 1995. Társadalom és nyelvhasználat. Szociolingvisztikaialapfogalmak. Budapest: Nemzeti Tankönyvkiadó.

KISS Jenő-PUSZTAI Ferenc (eds). 2003. Magyar nyelvtörténet. Budapest: Osiris Kiadó. 
LANSTYÁK István. 2006. Nyelvből nyelvbe. Pozsony: Kalligramm Könyvkiadó. LUKÁCS Antal. s.a. Fogarasföld autonómiája: keretek és korlátok. adatbank. transindex.ro/html/alcim_pdf1162.pdf.

2004. Documente Făgărăşene I (1486-1630). Documenta Transylvaniae Historica I., Bucharest.

NAGY Levente. 2012. Az erdélyi magyar és román reformáció román, magyar és nyugat-európai szemmel. In: MONOK István-NYERGES Judit-SIPOS Gábor (eds), Gondolatok a hungarológiáról. Előadások a VII. Nemzetközi Hungarológiai Kongresszuson. Budapest: Nemzetközi Magyarságtudományi Társaság, 41-68.

PÉNTEK János-BENŐ Attila. 2003. Nyelvi kapcsolatok, nyelvi dominanciák az erdélyi régióban. Cluj: Anyanyelvápolók Erdélyi Szövetsége.

PRODAN, David (ed.). 1970. Urbările Țării Făgăraşului. Bucharest: Editura Academiei Republicii Socialiste România.

SzT. - Erdélyi magyar szótörténeti tár I-XIV. 1976-2014. (I-VIII. Ed. Szabó T. Attila, I-IV. Kriterion Kiadó, Bucharest; V-VIII. Akadémiai-Kriterion, Budapest-Bucharest; IX-XI. Ed. Vámszer Márta, Budapest-Cluj-Napoca: Akadémiai-Erdélyi Múzeum-Egyesület; XII. Ed. Kósa Ferenc, Budapest-ClujNapoca: Akadémiai-Erdélyi Múzeum-Egyesület; XIII-XIV. Ed. Fazakas Emese, Cluj-Napoca: Erdélyi Múzeum Egyesület).

TAMÁS Lajos. 1966. Etymologisch-historisches Wörterbuch der ungarischen Elemente in Rumänischen. Budapest: Akadémiai Kiadó. 